\title{
Full mouth rehabilitation on the patient with class II jaw relation and posterior bite collapse using reestablishment of occlusal vertical dimension: a case report
}

\author{
Jae-Hyun Kim, Hye-Won Cho, Ji-Hye Jung* \\ Department of Prosthodontics, College of Dentistry, Wonkwang University, Iksan, Republic of Korea
}

Loss of molar support and abnormal jaw relationship lead to occlusal disharmony and cause pathologic signs. Full mouth rehabilitations with reestablishment of occlusal schemes are needed. In this case, the 75 year-old female patient showed posterior bite collapse, irregular occlusal plane and Class II jaw relationship. By observing her profile and interocclusal distance, she was diagnosed as loss of occlusal vertical dimension. Treatment plan is to restore maxillay class I removable partial denture and mandibular fixed prosthesis and to establish vertical dimension and harmonious occlusal plane. Occlusal vertical dimension of 19 $\mathrm{mm}$, which is obtained by $7.5 \mathrm{~mm}$ increase between maxillary right lateral incisor and mandibular canine, was established using temporary prosthesis via diagnostic wax-up. Patient adaptation with newly formed vertical dimension was verified during 8 week follow-up period. Within the information of interim prostheses, final restoration was constructed and delivered. The patient showed sound occlusal scheme and esthetic profile. (J Dent Rehabil Appl Sci 2015;31(3):262-72)

Key words: vertical dimension; full mouth rehabilitation; class II jaw relation; posterior bite collapse

\begin{abstract}
서론
구치부 교합지지가 상실된 경우 대합치가 정출하면서 교합평면의 붕괴가 일어나기 시작하며, ${ }^{1}$ 전치부의 마모 나 경사, 회전 등과 함께 수직교합고경이 감소되면 교합 부조화가 발생할 수 있다. ${ }^{2}$ 또한 저작근육의 수축이 정상 적으로 일어나지 않아 저작 기능이 떨어지고, ${ }^{2}$ 턱관절 통 증이나 장애 등 다양한 병적 징후가 나타나기도 한다. ${ }^{3}$ 수직교합고경의 감소는 하안면부의 심미성에 영향을 미 쳐, 구순 지지가 감소하거나 구각부에 주름이 생기는 등 노인성 안모의 원인이 되기도 한다. ${ }^{3}$ 임상적으로 정상적 인 교합의 유지나 회복이 불가능한 경우, 상하악의 교합 재설정을 통한 치료가 필요하다. 이는 수직고경의 거상
\end{abstract}

*Correspondence to: Ji-Hye Jung

Clinical Instructor, Department of Prosthodontics, College of Dentistry, Wonkwang University, 895, Muwang-ro, Iksan, 54538, Republic of Korea

Tel: +82-63-859-2938, Fax: +82-63-857-4824, E-mail: stop-it@hanmail.net

Received: June 22, 2015/Last Revision: July 23, 2015/Accepted: July 23, 2015
을 통해 보철물에 필요한 공간을 확보하면서 교합 재설 정을 시행하는 보철치료나 악교정수술이 동반된 교정치 료를 통해서 이루어진다.

수직교합고경의 거상을 통한 보철치료의 경우, 거상 양을 결정하기 위하여 생리적 안정위, 연하, 발음, 안모계 측 등 여러 방법이 제시되어 왔다. ${ }^{4}$ Dawson은 안정위가 매우 가변적이어서 수직고경의 결정에 역할을 할 수 없 다고 하였다. ${ }^{5}$ 그러나 아직까지 안정위는 동적이고 기능 적인 개념으로 악구강계의 기능과 심미를 회복하는데 있 어 가치 있는 기준으로 받아들여지고 있다. ${ }^{6}$ 교합 재설정 을 하는데 있어 고려해야 또 다른 요소는 환자의 악간 관 계이다. 특히 II급 악간 관계를 가진 환자의 교합은 전방 활주로에서 운동 범위가 크고 최대 개구량이 작다. 또한

Copyright@ 2015 The Korean Academy of Stomatognathic Function and Occlusion. (c) It is identical to Creative Commons Non-Commercial License. 
안정위에서의 교합면간거리가 1 급 악간관계를 보이는 환자의 경우 $2-2.5 \mathrm{~mm}$ 인데 비하여 2급 악간관계의 경 우 $3-5 \mathrm{~mm}$ 로 증가한다. ${ }^{7}$

완전 구강회복이란 구강 내 잔존치아와 결손치아를 모두 수복하여 저작과 발음 및 심미성을 회복시켜주는 것을 말한다. 치료 목표는 구치부에서 안정적인 최대교 두간접촉위 장애가 없는 군기능교합을 확립하고, 전치 부에서 적절한 수직 및 수평피개를 설정하여 전방유도 를 확립함으로써 저작기능을 회복하고 치료가 완료된 후에도 교합이 안정되는 것이다. ${ }^{8,9}$ 이 증례는 II급 악간 관계이면서 구치부 교합지지 상실로 인해 상하 치아가 서로 맞물리지 않아 저작이 힘들다는 주소로 내원한 환 자에서, 수직교합고경 증가를 통한 교합 재설정을 시행 하여 기능적이고 심미적인 완전구강 회복을 실현하였기 에 이를 보고하고자 하였다.

\section{증례 보고}

\section{1. 환자 개요 및 구강 내외 검사}

본 증례의 환자는 75 세 여성으로 이가 아프고 씹기가
어렵다는 주소로 본원에 내원하였으며 구강외과에서 파 노라마 촬영한 결과 수복된 다수의 치아에서 이차우식 과 치주질환이 나타났다(Fig. 1). 이에 따라 예후 불량한 상악 우측 구치부를 발거하고 치과 보철과로 의뢰되었 다. 의과적 병력은 전반적으로 건강한 상태였다.

초진 결과 환자는 상악 우측 견치와 소구치 및 대구치 가 결손되었고, 상악 좌측 중절치와 대구치도 결손되어 있었다. 하악은 양 제 2 대구치가 결손된 상태로, 좌측 제 2 소구치의 불량한 치축 경사와 회전 및 좌우 하악 제 1 대 구치의 임플란트 고정성 보철물의 저위교합으로 인해 구치부 교합지지가 약화되고 불균일한 교합평면을 보였 다. 상하 전치부에서 과도한 수직 및 수평 피개로 인해 가위교합(scissor's bite)이 형성되어 있으며(Fig. 2), 그

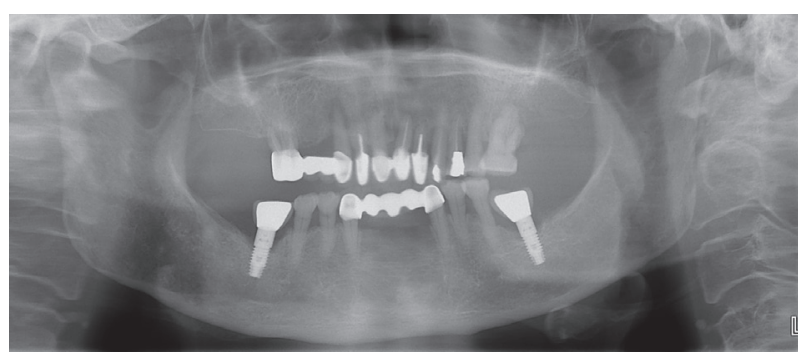

Fig. 1. Panoramic radiograph before treatment.
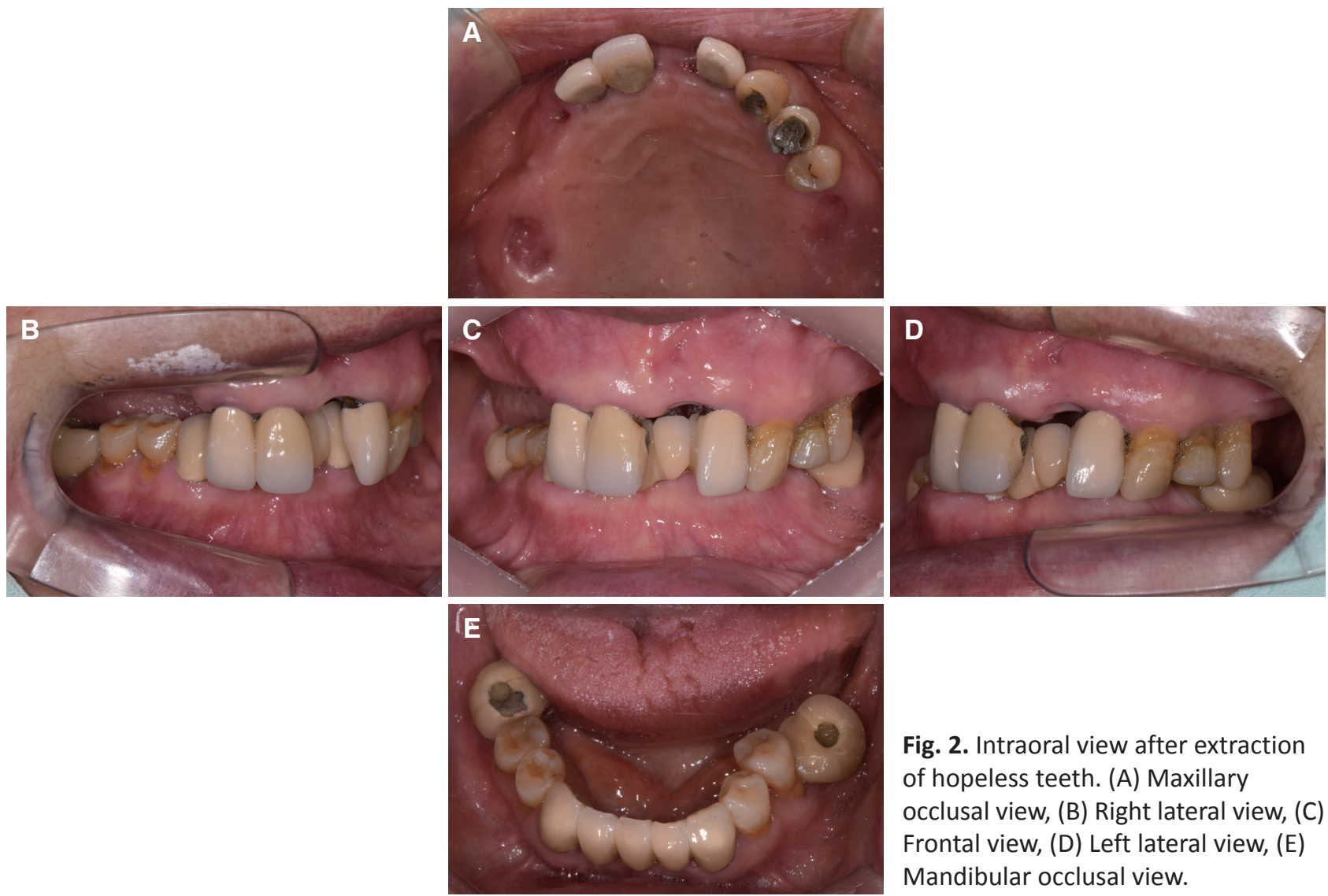

Fig. 2. Intraoral view after extraction of hopeless teeth. (A) Maxillary occlusal view, (B) Right lateral view, (C) Frontal view, (D) Left lateral view, (E) Mandibular occlusal view. 
밖의 비기능적 습관이나 턱관절 장애 증상은 나타나지 않았다. 안모를 관찰하였을 때 깊은 비순구와 굳게 다문 형태의 입, reverse smile line, 안면 표정근의 긴장도 상 실을 보여 수직고경이 감소된 환자의 특징을 나타내었 다. 따라서 위와 같은 문제점들을 바탕으로 좀더 명확한 진단을 내리기 위해 진단모형 분석을 실시하였다.

\section{2. 진단 모형 분석과 치료계획의 수립}

예비 인상을 채득하여 진단 모형을 제작하고 Dawson 의 양수조작법을 이용하여 중심위를 채득하고 안궁이 전을 시행하여 반조절성 교합기(KaVo PROTAR evo 7, $\mathrm{KaVo}$ Corp., Biberach, Germany)에 부착하였다. 모형 분석 결과, 상악 좌측 제 2 소구치와 하악 좌측 제 1 대구치 에서만 교합접촉이 이루어지고 있으며, 하악 우측 견치 는 상악 구개부의 연조직에 접촉되는 상태로 심한 가위 교합을 보이고 있었다. 하악 자연치열의 교합평면은 좌 측이 우측에 비해 다소 높았고 제 1 대구치의 저위교합으
로 인해 매우 불균일한 상태였다. 또한 치주지지가 불량 한 상악 좌측 측절치와 제 1 대구치는 발거 하기로 하였 다.

상악 우측 측절치와 하악 우측 견치의 zenith line을 기 준으로 수직교합고경을 측정한 값은 $11.5 \mathrm{~mm}$ 로서 평균 치인 18 - $20 \mathrm{~mm}$ 에 크게 미치지 못하였다(Fig. 3). ${ }^{10}$ 이상 의 분석 결과 전치와 좌측 소구치부에서의 과개교합과 구치부의 지지 상실로 인해 수직고경의 감소를 동반한 교합 붕괴로 진단하고, 완전구강회복의 필요성을 환자 에게 설명하고 동의를 구했다.

환자의 나이와 경제적인 형편을 고려하여 상악 결손 부를 임플란트지지 고정성 보철물 대신 Kennedy Class I modification 1 국소의치로 수복하도록 결정하였고 국 소의치를 위한 악간 간격을 확보하고 조화로운 교합평 면을 형성하기 위해 환자의 수직고경을 증가시키기로 치료계획을 수립하였다. 수직교합고경의 거상량을 결정 하기 위해 생리적 안정위와 연하 역치 및 Willis 법을 복 합적으로 이용하였다(Fig. 4). 이 때 수직고경의 거상량
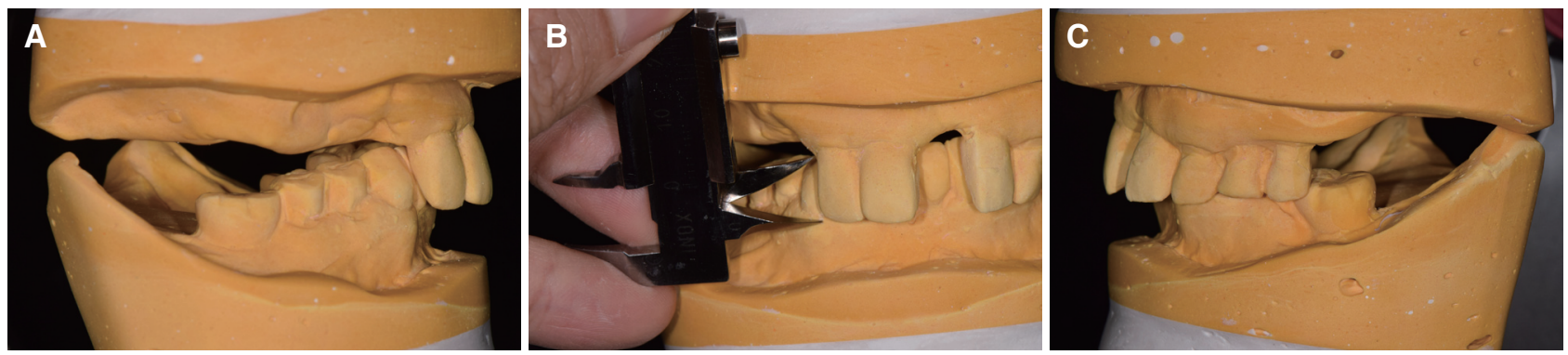

Fig. 3. Mounted diagnostic model analysis. (A) Posterior collapsed bite on right side and mandibular canine had a contact with soft tissue of maxillary palate, (B) Intergingival distance between zenith lines of right maxillary lateral incisor and mandibular canine was $11.5 \mathrm{~mm}$, (C) MICP contact between the maxillary left 2nd bicuspid and mandibular 1st molar.
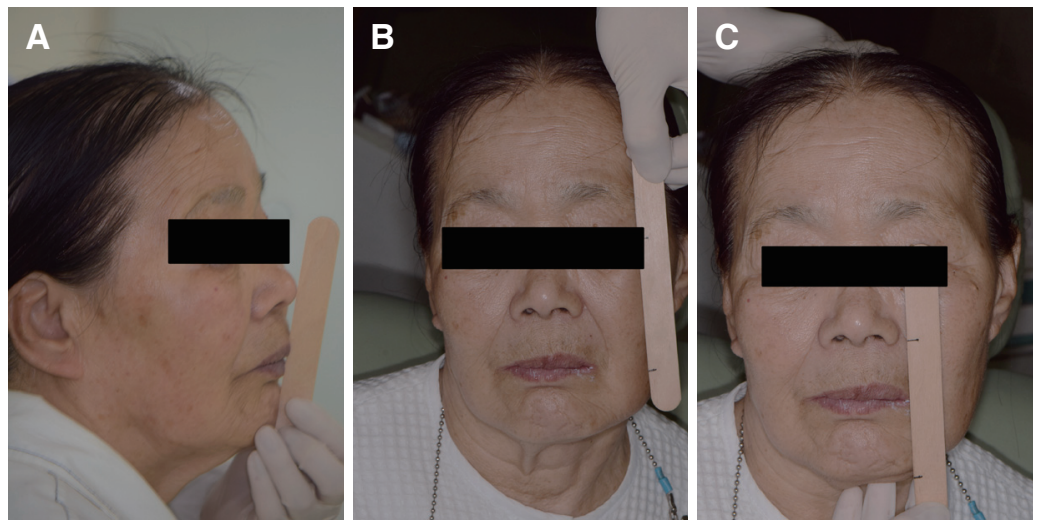

Fig. 4. Determination of vertical dimension. (A) Physiologic resting position, (B) Measurement of distance between the pupil and mouth corner using Willis method, (C) Measurement of length of lower $1 / 3$ of the face using Willis method. 
은 상악 우측 측절치와 하악 견치 사이의 치은연간 거리 를 기준으로 $7.5 \mathrm{~mm}$ 증가시킨 $19 \mathrm{~mm}$ 로 결정하였으며 임시치아 수복 단계에서 조절이 가능하도록 계획하였 다.

진단용 납형을 형성하기 위해 먼저 교합기의 incisal guide pin을 $7.5 \mathrm{~mm}$ 거상하고, 하악 잔존치아 교합면에 전후 및 측방 만곡을 부여하여 이상적인 교합평면을 형 성하였다. 최종적으로 교합면 형판을 이용하여 점검하 고 납형을 완성하였다. 대합되는 상악 잔존치아는 결정 된 수직교합고경에 맞추어, 적절한 전방유도와 군기능 교합이 가능하도록 납형을 형성하고 결손부는 임시의치 를 위한 인공치를 배열하였다(Fig. 5). 상하악의 임시 고 정성 보철물을 제작하기 위해 앞서 이상적으로 진단 납 형 형성한 모형을 복제한 뒤 putty index를 제작하고 이 를 이용하여 임시보철물 쉴(shell)을 만들었다. 상악의 진단 납형 형성 및 치아배열 한 모형을 매몰 및 레진 온 성하여 임시 가철성 국소의치를 제작하였다.

\section{3. 지대치 삭제와 임시 수복물의 장착 및 평가}

II급 악간 관계에서는 전방운동 시 하악의 이동량이 크고 상하악 전치의 길이와 순설적 위치, 상악 전치 설면 의 형태에 따라 다양한 전방유도의 형태가 가능하다. ${ }^{7}$ 상 하 잔존치아의 기존 수복물을 제거하고 지대치 형성한 다음 임시보철물 shell을 개면하여 고정성 임시 보철물을 제작하고 시적하였다. 상순의 지지도와 $\mathrm{F}$ 발음을 이용해 상악 전치의 길이와 수평적 위치를 조절하였다. S 발음 을 이용해 하악 전치의 위치와 길이를 대략적으로 잡은 다음, 상악 기록상을 이용하여 수직교합고경을 우측 측 절치 zenith line에서 $19 \mathrm{~mm}$ 로 증가시켜 중심위를 채득 하였다(Fig. 6). 이차 모형을 교합기에 부착하여 진단용 왁스업을 확인하고 상악 임시의치를 제작하였다.

잔존 자연치인 상악 좌측 견치, 제 1 소구치와 제 2 소구 치, 하악 좌우 제 1 소구치와 제 2 소구치를 임시적으로 삭 제하고 진단용 납형을 기초로 고정성 임시 보철물을 제
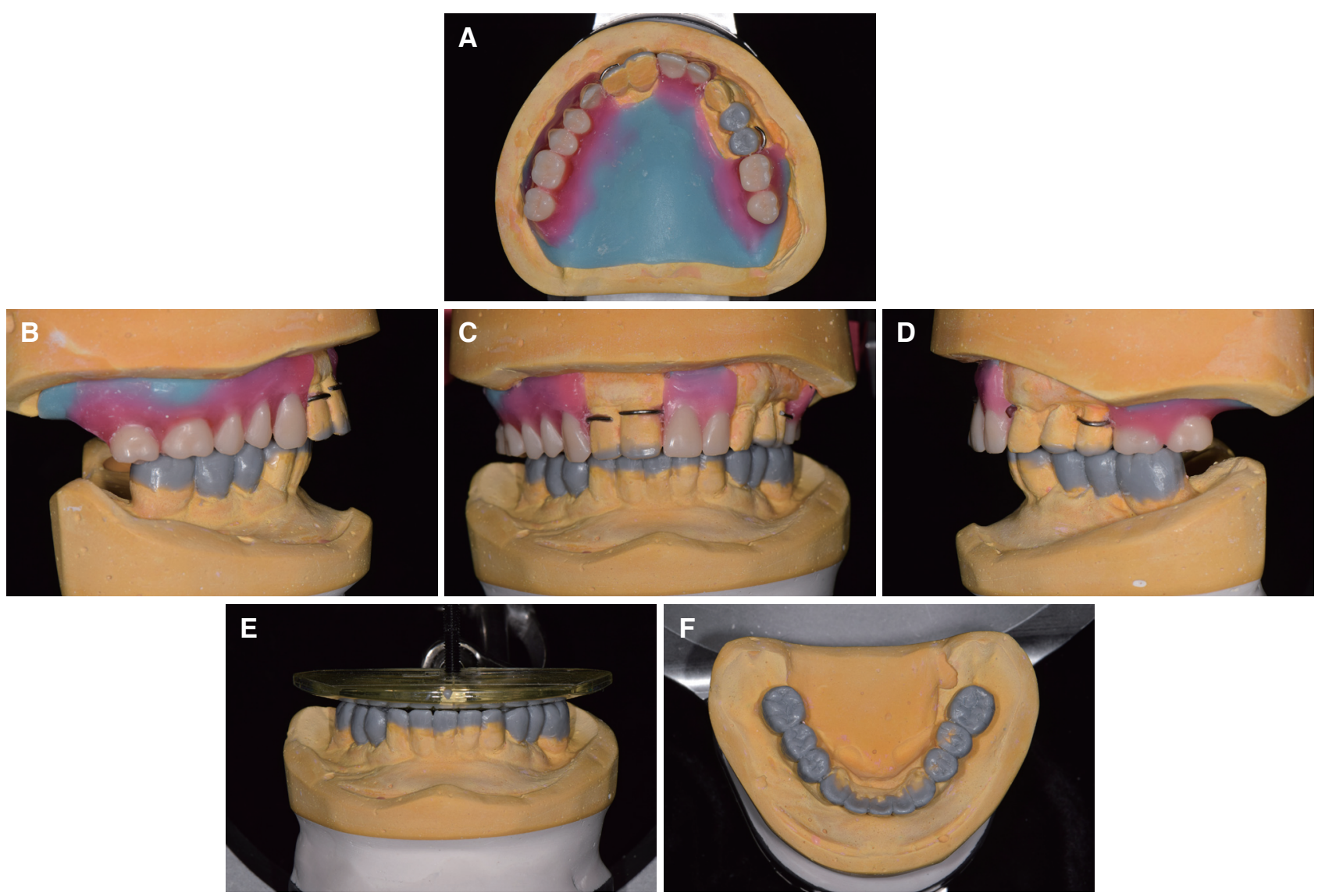

Fig. 5. Diagnostic wax up using new vertical dimension for interim prostheses. (A) Maxillary occlusal view, (B) Right lateral view, (C) Frontal view, (D) Left lateral view, (E) Harmonious occlusal plane establishment using occlusal plane guide, (F) Mandibular occlusal view. 

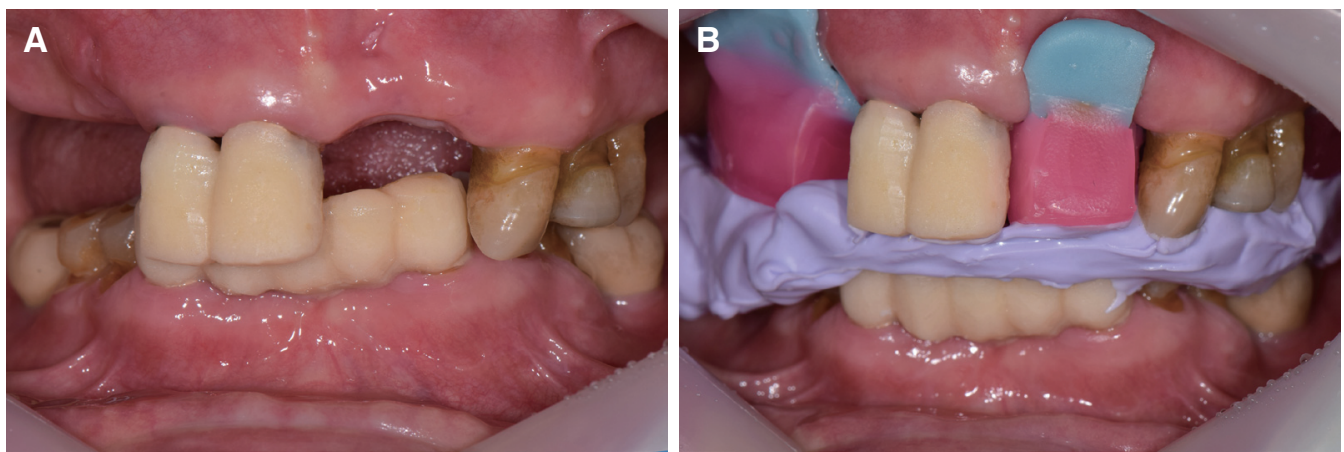

Fig. 6. (A) Newly placed temporary fixed partial denture (FPD) after removal of old FPD, (B) New centric relation record with increased vertical dimension.
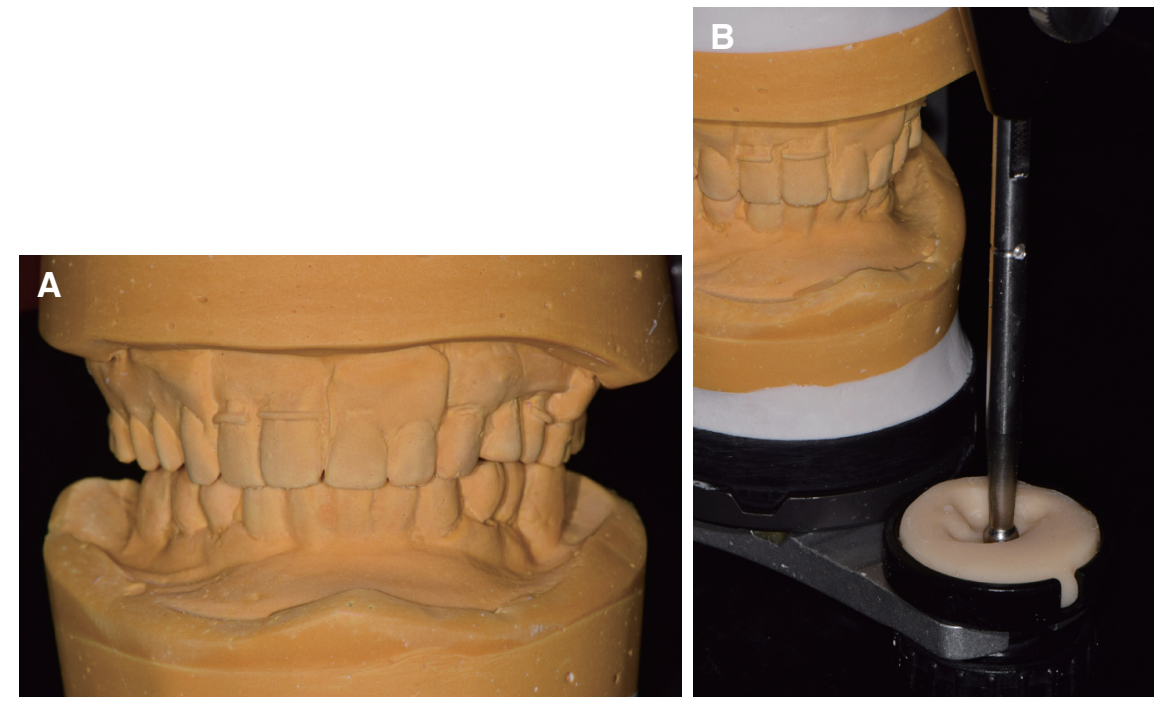

Fig. 7. (A) Mounted models after temporization, (B) Fabrication of customized anterior guide table.

작하였으며, 상악 임시의치를 장착하고 교합조정하였 다. 수직거상을 하면 하악이 시계방향으로 회전하면서 II급 악간 관계의 경향이 더욱 심해져 전방유도가 어려 우나, Jensen ${ }^{7}$ 이 추천한 바와 같이, 하악의 전방운동 시 견치가 접촉되기 전까지 소구치에서 유도를 담당하게 하였다.

임시보철물은 2주 간격으로 내원하면서 8주간 사용하 게 하였으며, 설정한 수직고경에 대한 환자의 적응 여부 를 평가하였다. 약간의 교합 조정 후, 이상 소견이나 불 편감이 없었으므로 임시수복물의 상태로 상하악 인상을 채득하고 모형을 교합기에 부착하여 맞춤 전방유도판을 제작하였다(Fig. 7).

\section{4. 최종 인상 채득과 고정성 보철물의 제작}

최종 보철물 제작을 위해 상하악 지대치의 삭제를 완 료하고 하악 양측 제 1 대구치 부위의 임플란트에 인상 용 지대주를 연결한 후 실리콘 인상재(Honigum, DMG, Hamburg, Germany)로 정밀 인상을 채득하여 작업모형 을 제작하였다(Fig. 8). Anterior jig를 이용하여 중심위 를 채득하고 교합기에 이미 부착된 임시 보철물 모형과 cross-mounting하여 최종 주모형을 교합기에 부착하였다.

하악 전치부와 구치부에 최종 수복물 형태로 납형을 형성한 다음 되깎이 과정을 거쳐 금속 코핑을 제작한 뒤 구강 내 시적 후 적합을 확인하고 상악 임시의치에 준해 

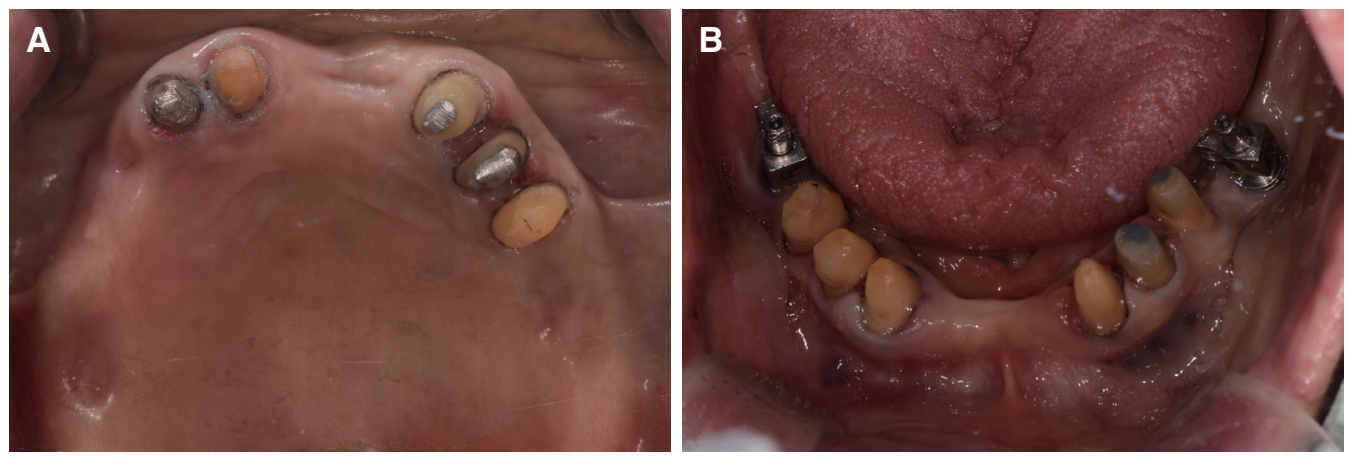

Fig. 8. Abutment preparation for definitive prosthesis. (A) Maxillary occlusal view, (B) Mandibular occlusal view.
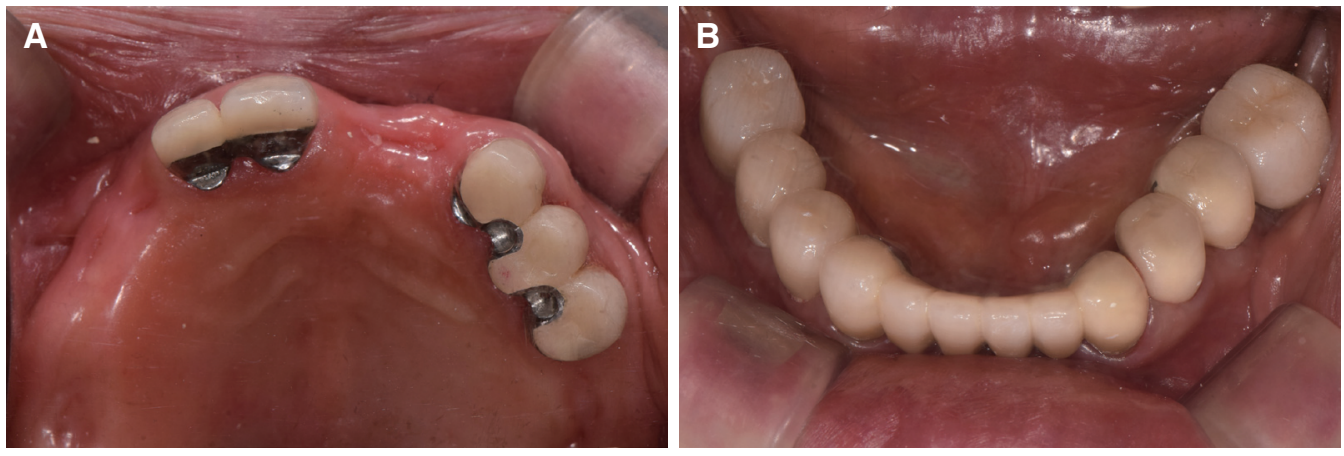

Fig. 9. Deivery of definitive FPDs with increased vertical dimension. (A) Maxillary occlusal view, (B) Mandibular occlusal view.

교합면 도재를 축성하였다. 양측 견치를 지대치로 하는 전치부 6 본 금속도재 고정성국소의치와 좌우 제 1 소구 치, 제 2 소구치 및 양측 제 1 대구치 부위 임플란트는 각각 단일 도재금속관의 형태로 제작하였다(Fig. 9).

\section{5. 상악 국소의치의 제작}

상악 국소의치에서 좌측 전치부 결손부위는 우측 지 대치의 불리한 치관 대 치근 비율로 인해 장기적인 예후 를 확신하기 어려웠기 때문에, 고정성 보철물 대신 국소 의치의 추가결손부위로 수복하고, 우측 지대치 발거 시 과도의치로 사용할 수 있도록 국소의치를 설계하였다. 진단용 납형과 임시수복물의 형태를 기준으로 상악 고 정성 보철물의 근원심 폭경과 형태를 재현하였으며, 맞 춤 전방 유도판과 인덱스를 이용하여 상악에 두 개의 고 정성 국소의치를 제작하고 구강 내에 시적 및 임시 합착 하였다(Fig. 9).

자가 중합형 트레이레진(Ostron 100, GC Dental
Products Corp., Kasugai, Japan)으로 제작한 개인트레 이를 모델링 콤파운드로 변연 형성한 후 폴리설파이 드 인상재(Permlastic, Kerr Corporation, Romulus, MI, $\mathrm{USA}$ 로 최종인상을 채득하였다(Fig. 10A). 국소의치를 위한 주모형을 제작한 후 서베잉하여 금속구조물을 설 계하였다. 주연결장치는 우측 측절치와 좌측 제 2 소구 치를 최후방 지대치로 하는 complete palatal plate type connector로 결정하였다. 직접유지장치는 의치의 기능 운동을 허용하기 위해 좌측 제 2 소구치에 RPI 클라스프 를 설계하고, 의치의 기능운동 시 가해질 수 있는 지대 치의 측방력을 줄이기 위해 우측 측절치에는 가공선 유 지암을 설계하였다. 간접유지장치로는 좌측 중절치 설 면 레스트와 우측 제1소구치 근심 레스트를 설계하고 각 지대치 인접면에 유도판을 형성하여 의치의 유지, 지 지, 안정을 증진시키고자 하였다(Fig. 10B). 완성된 금속 구조물은 구강 내에 시적 하여 적합도를 확인한 후 교합 제를 제작하고 악간관계를 채득하여 상악 주모형을 교 합기에 부착하였다. 

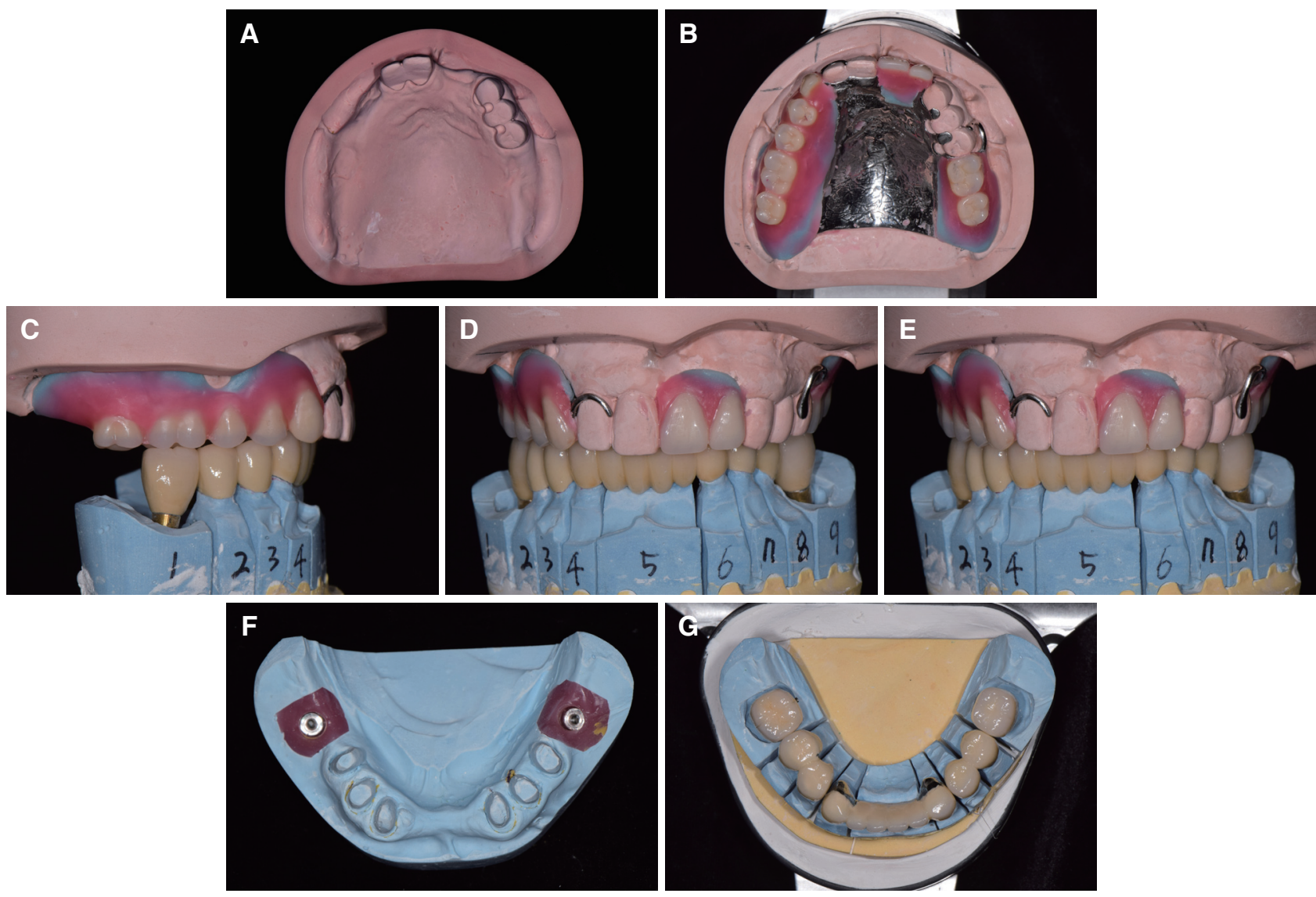

Fig. 10. Definitive prostheses. (A) Maxillary master cast, (B) Maxillary occlusal view of removable partial denture, (C) Right lateral view, (D) Frontal view, (E) Right lateral view, (F) Mandibular working cast, (G) Mandibular occlusal view of metal ceramic restoration.

\section{6. 최종 보철물의 완성과 장착}

구치부에서의 교합양식은 중심위에서 좌측은 상하 고 정성 보철물, 우측은 하악 고정성 보철물과 상악 국소의 치에서 안정적인 최대교두간접촉위를 확립하였다(Fig 10C - 10F). 편심위에서는 상하악 전치가 기능적으로 유 도되는 전방운동이 가능하게 하였고, 상악 국소의치의 인공치에 맞추어 하악 금속 도재 보철물의 교합면을 완 성하여 우측 구치부의 군기능 교합이 조화되도록 제작 하였다. 상악의 악궁이 넓고 잔존치조제가 풍융하며 인 공치가 잔존치조제 정상에 배열되어, 좌우 측방운동 시 에도 의치의 안정성이 저해되지 않았기 때문에 양측성 균형교합이 아닌 군기능 교합으로 설정하였다. 광택소 성 과정을 거쳐 완성한 하악 고정성 국소의치와 제1대 구치의 임플란트지지 고정성 국소의치를 임시 합착하였
다. 상악 납의치를 시적하여 설정한 교합양식 및 임시보 철물에서 회복한 수직고경이 유지되고 있는지 확인한 후 매몰, 레진 온성 과정을 거쳐 상악 국소의치를 완성 하였다.

완성된 국소의치를 시적하고 교합기 재 부착과정을 통해 교합조정을 시행하였다. 구강 내에서 수직고경을 재확인하고 전방운동 시 fremitus 여부와 의치 삽입 철 거 시 수직고경의 변화가 있는지 확인하였다(Fig. 11). 환자는 저작기능을 회복하고 정상적인 안모에 가까워졌 으며 장착 후 구강위생관리와 의치 관리에 관한 교육을 시행하였다. 최종 수복 후의 측두하악관절 방사선사진 에서 안정적인 과두 위치를 확인하였고(Fig. 12) 현재 3 개월의 임상적 및 방사선상의 주기적 경과 관찰이 이루 어지고 있으며 심미적, 기능적으로 만족할 만한 결과를 얻을 수 있었다. 

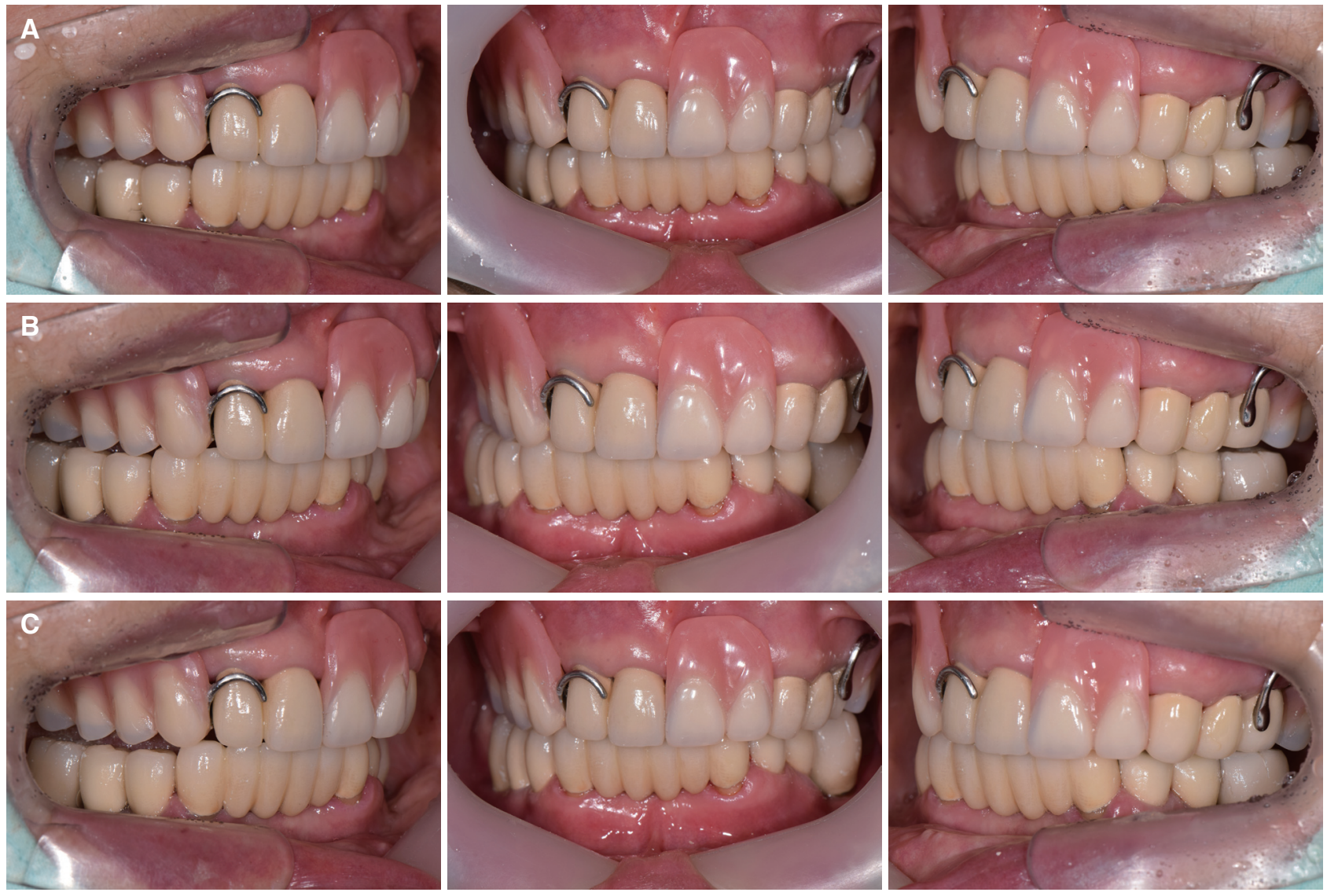

Fig. 11. Establishment of occlusal scheme. (A) Left lateral movement, (B) Right lateral movement, (C) Protrusion.
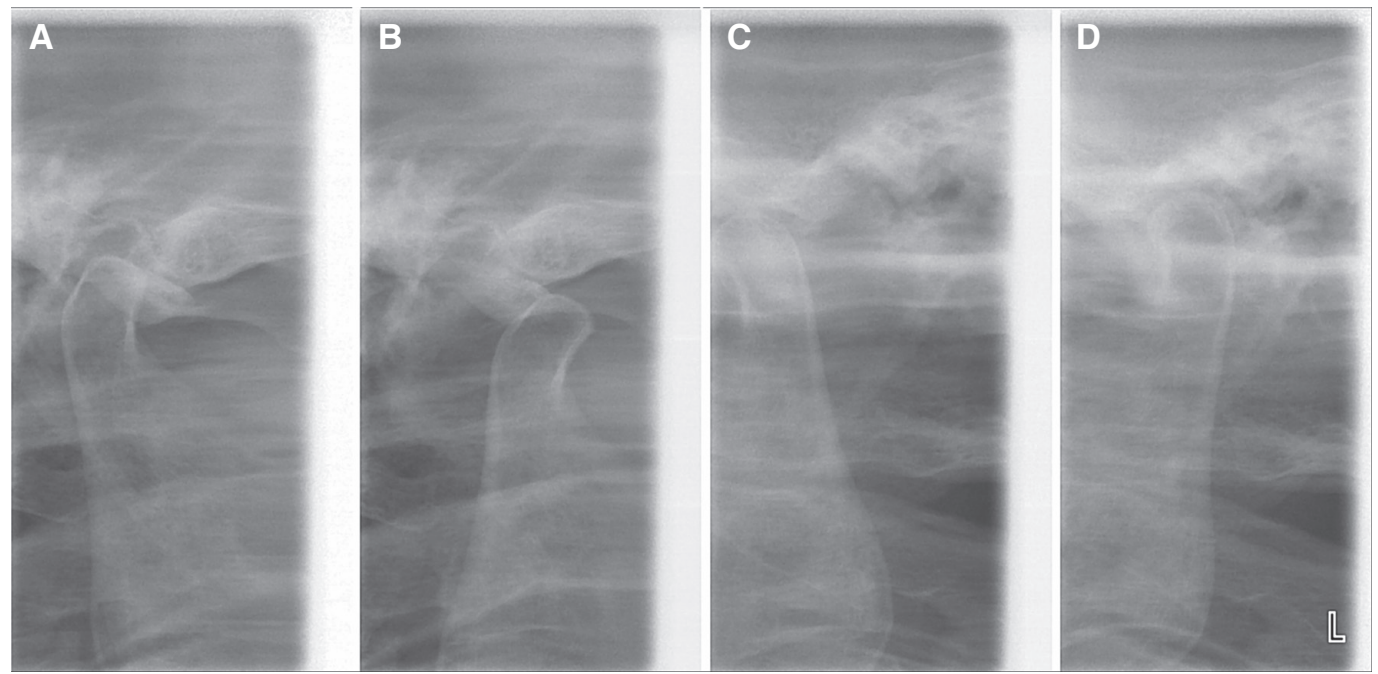

Fig. 12. TMJ radiograph series after treatment. (A) Centric occlusion (Rt side), (B) Maximum opening (Rt side), (C) Maximum opening (Lt side), (D) Centric occlusion (Lt side). 


\section{고찰}

수직교합고경을 측정하기 위해서 다양한 방법이 사용 되고 있으며 한가지 방법만 사용하기는 어려워 복합적 으로 이용하고 있다. 발치 전 기록이 있다면 수직고경을 확인할 수 있어 유용하나, ${ }^{11}$ 수직교합고경을 상실한 경 우에는 생리적 안정위를 이용하여 유추한다. ${ }^{6}$ 환자를 직 립위로 앉히고 안정위 수직고경을 계측한 다음 교합면 간 거리 2-4mm를 감해 수직교합고경을 결정하게 된 다. 또한 연하와 발음을 참고할 수 있는데, 수직 고경 평 가에 주로 사용되는 발음으로는 "M", "S" 등이 있다. 안 모의 심미성을 이용하여 수직고경을 계측하는 방법으로 하안면부의 조화와 상하순의 형태, 하순과 이부의 외형 등을 참고로 하기도 한다. ${ }^{12}$ Willis는 코 아래 bony shelf 부터 하악 하부까지의 하안면 $1 / 3$ 의 길이가 동공에서 구각부까지의 거리와 일치할 수 있다고 제시하였다. ${ }^{13}$

이 증례에서 상하악 전치부 zenith line을 기준으로 한 치은연 사이의 거리를 측정한 바 $11.5 \mathrm{~mm}$ 로 평균치인 18 - $20 \mathrm{~mm}$ 보다 매우 적었으며, 안모를 관찰한 결과 수 직교합고경의 회복이 필요하다고 진단하였다. 수직교합 고경을 결정하기 위해 Willis법에 따라 안모의 심미성을 회복하는 정도로 상악 교합제를 조정하고, 구강 내에서 “M”발음과 연하역치를 이용해 생리적 안정위를 계측하 였다. 또한 전치부의 심미성과 "F, S"발음을 이용해 상 하 전치의 길이와 순설적 위치를 결정하였다. 이들 계측 치를 통합해 전치부 치은연간 거리를 기준으로 $7.5 \mathrm{~mm}$ 의 거상량을 결정하고 상악 국소의치와 하악 고정성 보 철치료를 진행하였다.

일반적으로 전치부에서 $5 \mathrm{~mm}$ 이내의 수직교합고경 거상은 생리적으로 허용할만한 범주라고 하나, 교합면 간 거리는 2-4 $\mathrm{mm}$ 로 범위의 형태로 존재하며, 필요하 면 환자의 적응력에 따라 그 이상의 거상이 가능하다. ${ }^{10}$ 따라서 수직고경을 거상하였을 때는 환자의 근신경계 적응 범주 내에 있는지 확인하는 것이 중요하며, 본 증 례에서도 임시보철물을 장착한 상태에서 충분한 기간 동안 평가하여 확인하였다. 만일 재설정된 수직고경이 생리적 범위를 벗어난다면 2주 안에 부정적인 증상을 나타내었을 것이다. ${ }^{14}$ 본 증례는 상악 국소의치 제작을 위하여 $7.5 \mathrm{~mm}$ 를 거상하여 일반적인 허용치인 $5 \mathrm{~mm}$ 를 초과하였으나 생리적 범위 내에 있어 근신경계가 잘 적 응하였다고 볼 수 있다. ${ }^{10,15}$

Williamson과 Lundquist ${ }^{16}$ 는 편심위 운동 시 적절한
전방유도에 의해 작업측을 제외한 구치부가 모두 이개 되어야 근신경계의 생리적 안정에 도움이 되며, 견치 의 접촉 여부보다 구치부에서의 장애가 없는 교합이 훨 씬 효과적이라고 하였다. II급 악간관계 환자는 최대교 두간접촉위에서는 구치부만 접촉하고, 측방운동 시에 군기능교합 혹은 약한 양측성 균형교합의 성향이 있다. 그러나 하악의 전방 운동 시 전치부 접촉이 늦게 시작 되며, 전치부가 접촉하기 전까지 소구치에서 전방운동 을 유도하게 되고 안정위에서는 3-5 $\mathrm{mm}$ 의 긴 교합면 간 거리가 존재한다. ${ }^{7}$ 수직교합고경을 증가시키면 하악 의 시계방향 회전으로 인해 2 급 악간 관계의 경향이 더 욱 심화된다. 이 증례에서도 전방 운동시 소구치부에서 전방운동을 보조하도록 하고 절단연에서는 end-to-end relation이 되도록 조절하였다.

\section{결론}

본 증례는 구치부 지지 상실 및 교합평면을 고려하지 않은 보철물과 2 급 악간관계에 따른 전치부의 심한 과 개교합으로 인해 교합평면의 부조화를 보이는 환자의 수직교합고경을 거상하고 임시 보철물을 사용하여 적응 여부를 평가하였다. 8주 후 심미적, 기능적 적응에 문제 가 없어 상악 고정성 및 가철성 국소의치, 하악 고정성 보철물을 사용하여 교합을 재설정하였다. 상하악에 이 상적인 형태의 보철물을 형성하여 최대교두간접촉위에 서의 교합접촉을 확립하였고 전방유도를 유지하였으며, 생리적인 범위 내에서 교합고경의 거상이 이루어지도록 노력하였다. 현재 3 개월의 관찰 기간 동안 턱관절 증상 및 보철물 파절 등의 특이할 만한 합병증은 보이지 않았 고 이후에도 주기적인 평가가 필요할 것으로 생각된다.

\section{Orcid}

Jae-Hyun Kim http://orcid.org/0000-0001-5573-1140

Hye-Won Cho http://orcid.org/0000-0003-0623-5647

Ji-Hye Jung http://orcid.org/0000-0003-3322-4011

\section{References}

1. Verrett RG. Analyzing the etiology of an extremely worn dentition. J Prosthodont 2001;10:224-33.

2. Winstanley RB. A retrospective analysis of the 
treatment of occlusal disharmony by selective grinding. J Oral Rehabil 1986;13:169-81.

3. Rugh JD, Drago CJ. Vertical dimension: a study of clinical rest position and jaw muscle activity. J Prosthet Dent 1981;45:670-5.

4. Fayz F, Eslami A. Determination of occlusal vertical dimension: a literature review. J Prosthet Dent 1988;59:321-3.

5. Dawson PE. Functional occlusion from TMJ to smile design. 1st ed. New York ; Elsevier Inc.; 2007. p. 114-9.

6. Mack MR. Vertical dimension: a dynamic concept based on facial form and oropharyngeal function. J Prosthet Dent 1991;66:478-85.

7. Jensen WO. Occlusion for the Class II jaw relations patient. J Prosthet Dent 1990;64:432-4.

8. Wassell RW, Steele JG, Welsh G. Considerations when planning occlusal rehabilitation: a review of the literature. Int Dent J 1998;48:571-81.

9. Kobayashi Y, Shibuya H, Nagano T, Yanagita S. Treatment of the temporomandibular joint dysfunction patient by full mouth occlusal reconstruc- tion (author's transl). Shigaku 1975;63:79-93.

10. Bloom DR, Padayachy JN. Increasing occlusal vertical dimension-why, when and how. Br Dent J 2006;200:251-6.

11. Aboul-Ela LM, Razek MK. Pre-extraction records of the occlusal plane and vertical dimension. J Prosthet Dent 1977;38:490-3.

12. Mack MR. Perspective of facial esthetics in dental treatment planning. J Prosthet Dent 1996;75:16976.

13. Willis FM. Features of the face involved in full denture prosthesis. Dent Cosmos 1935;77:851-54.

14. Abduo J, Lyons K. Clinical considerations for increasing occlusal vertical dimension: a review. Aust Dent J 2012;57:2-10.

15. Turner KA, Missirlian DM. Restoration of the extremely worn dentition. J Prosthet Dent 1984;52: 467-74.

16. Williamson EH, Lundquist DO. Anterior guidance: its effect on electromyographic activity of the temporal and masseter muscles. J Prosthet Dent 1983; 49:816-23. 


\section{구치부 교합지지가 상실된 프급 악간관계 환자의 교합 재설정을 통한 완전 구강회복 증례}

\section{김재현, 조혜원, 정지혜*}

원광대학교 치과대학 치과보철학교실

구치부 교합지지 상실과 비정상적 악간 관계는 교합 부조화로 이어지며 다양한 병적 징후를 동반한다. 저작, 심미 및 발음 기능을 회복하기 위해 교합고경과 교합평면 재설정에 따른 완전구강회복이 필요하게 된다. 본 증례는 75 세의 여 성으로 교합지지 상실과 불균일한 교합평면 및 II 급 부정교합을 가지고 있었다. 안모를 관찰하고 악간관계를 평가한 결과 상하악의 최대교두간접촉위가 상실되면서 수직교합고경이 감소된 것으로 진단되었다. 상악 국소의치와 하악 고 정성보철물로 상실된 교합수직고경을 회복하고 조화로운 교합평면을 형성하였다. 수직고경 거상량은 $7.5 \mathrm{~mm}$ 로 하였 고, 임시보철물을 이용하여 8 주간 경과 관찰 후 최종 보철물을 제작하였으며 저작효율과 심미성은 개선되었다.

(구강회복응용과학지 2015;31 (3):262-72)

주요어: 수직고경; 완전구강회복; 2급 악간 관계; 구치부 교합붕괴 